\title{
State Ownership, Legal Institution, and Independent Director Compensation: An Exploratory Study in China
}

\author{
Dr. Pattarin Adithipyangkul \\ School of Accounting \\ Curtin University of Technology \\ GPO Box U1987 \\ Perth WA 6845 \\ Australia \\ Tel: +61089266 7787 \\ Fax: +61089266 7196 \\ E-mail: P.Adithip@curtin.edu.au
}

\author{
Dr. T. Y. Leung* \\ Lee Shau Kee School of Business Administration \\ Open University Hong Kong \\ 30 Good Shepherd Street \\ Ho Man Tin, Kowloon, Hong Kong \\ Tel: (852) 27686949 \\ E-mail: tyleung@ouhk.edu.hk
}

\footnotetext{
${ }^{*}$ Corresponding author
}

This research is supported by the Open University of Hong Kong Research Grant (No. 2012/2.1). 


\title{
State Ownership, Legal Institution, and Independent Director Compensation: An Exploratory Study in China
}

\begin{abstract}
This study examines the determinants of independent director compensation in China, with particular interest in the impacts of state ownership and legal institution. Controlling for the characteristics of directors, boards, and firms, we find independent director compensation is positively related to attributes of director's human and social capital such as education, effort, professional expertise, and connection (guanxi). We show that independent director pay is determined differently across the ownership structures. Independent directors are paid less in companies owned by local government units and the independent directors in such companies are paid less in a region with more developed legal institution. This study contributes to the limited literature on independent director compensation by extending beyond the market economies to explore the determinants of independent director compensation in a transitional economy like China. It also adds to the literature on legal institutions by examining the impacts of legal development on compensation. Finally, this study informs the public of the current compensation practice, which will facilitate future policy making.
\end{abstract}

Keywords: Compensation; Guanxi; Legal Institution; State Ownership

JEL Classification: M41, M52 


\section{State Ownership, Legal Institution, and Independent Director Compensation: An Exploratory Study in China}

\section{Introduction}

The function of independent directors is to enhance corporate governance, and compensation can influence independent director behavior. Despite its importance in motivating director's performance, the literature on non-executive director compensation is still limited, and much of the previous research has been conducted in the US setting (Hahn and Lasfer, 2011). Very little is known about non-executive director compensation in transitional economies. This paper examines the determinants of independent director compensation in China. Owing to China's distinctive cultural and institutional background, western theories may not always apply to Chinese phenomena, and research in Chinese settings is important theoretically. From the start of the economic reform in 1978 to 2013, China's trade volume has increased from US\$20.6 billion to US $\$ 4,160$, billion (Soong, 2014). As Chinese economy continues to grow, China will become more interdependent with many countries worldwide, and it is important to learn more about China for the research to be 'globally relevant' (Peng, 2004).

Although it is commonly believed that independent director compensation is determined at the firm level, recent research in the western settings shows that independent director compensation is determined by director's individual factors (see e.g., Cordeiro et al., 2000). Informed by the previous studies, we investigate the determinants of independent director compensation at the director-firm-year observation level. In this paper, we test whether director human capital is priced in a transitional economy like China. We focus on certain aspects of director human capital, i.e., education, effort, and professional expertise. For the sake of brevity, below, we use the word 'human capital' to collectively refer to these various aspects of human 
capital. Additionally, we investigate whether directors are compensated for their social capital such as connections (guanxi). We also investigate the impacts of state ownership and legal institution on independent director compensation. In 1978, China began an economic reform, and the market-oriented policies have been adopted (Das 2012). Coinciding with the economic reform was the legal reform to enhance the legal institutions and to develop the legal system that supported economic growth (Clarke, 2007). After more than three decades of the reform processes, both the market and legal institutions have been enhanced; however, the degrees of market and legal development still vary significantly across regions (Wang et al., 2008). China thus provides an excellent research setting to investigate the impacts of legal development, without the cross-country confounding factors which are present in the previous international studies.

Our main findings are as follows. First, consistent with the previous studies in market economies, we find that independent directors are compensated for their human capital (professional expertise, education, and effort) in China. Directors are also compensated for their social capital (connections or guanxi). Second, we show that director attributes and organizational context interact to determine independent director compensation. Some attributes of an independent director are likely to be more valuable for a certain type of organization and hence tend to be compensated more in such an organization. In particular, we find that director professional expertise and effort tend to be more valuable in a privately-owned enterprise. Third, with the socialist legacy, social harmony and equality are important, and pay disparity is a concern in China (Firth et al., 2010; Lin and Lu, 2009; Lum, 2006). Our results show that the social equity pressure tends to have stronger impact on an enterprise controlled by a local government unit than an enterprise owned by the central government or a privately-owned enterprise, possibly because of the local cadre responsibility system imposed on local government 
officials (Minzner, 2009). We find that independent director pay is more suppressed in a local state-owned enterprise in a region with more developed legal institution.

Our study contributes to the limited literature on independent director compensation by extending beyond market economies to explore the determinants of independent director compensation in a transitional economy like China. Our study also adds to the literature on legal institutions by examining the impacts of legal development on compensation. By using data from China, a huge country with much variation in the degree of legal development, we can avoid the cross-country confounding factors which are present in the previous international studies. In addition to the research contribution, this study is useful for policy making. Although both independent director and compensation are important governance tools, there is currently no official guideline on independent director compensation in many countries (Hahn and Lasfer, 2011). A policy maker may be hesitant to impose specific guidelines or requirements because little is known about non-executive director compensation and its impacts. By informing the public of the current practice, our study can facilitate future policy making, which will improve corporate governance in the long run. Our findings also inform the industry of the current compensation practice so that companies can learn from their peers to improve their remuneration policies.

\section{Theoretical Framework and Hypotheses}

\subsection{Independent Directors in China}

The China Securities Regulatory Commission (CSRC) issued its 'Guideline for Introducing Independent Directors to the Board of Directors of Listed Companies' in 2001, which requires that at least one third of the directors must be independent by June 30, 2003, and that independent directors must constitute at least half of the compensation, audit, and nomination 
committees if the companies have them (Clarke, 2006; Xi, 2006). The CSRC, however, did not issue a guideline regarding director compensation. Equity incentive for independent directors is not used much in China; in most cases, independent directors are compensated in terms of cash allowances (Liu and Fong, 2010).

In the western settings, non-executive directors play three important roles: monitoring, counselling and facilitating the acquisition of necessary resources (Hahn and Lasfer, 2011). While previous research suggests that independent directors in Chinese firms are valued for their roles as a business facilitator or advisor (Clarke, 2006), it appears that firms do not hire them to monitor $(\mathrm{Xi}, 2006)$. The nature of agency problems is different in China. Most of the listed companies in China are either state-owned or family-owned (Amit et al., 2009). With powerful controlling shareholders, the agency problems include both the agency problems between major shareholders and minority shareholders and between shareholders and managers (Clarke, 2006). Although the CSRC guideline seems to be successful in ensuring the presence of independent directors on board, in practice whether the guideline can actually improve the monitoring of top management or the protection of minority shareholders remains doubtful (Clarke, 2006; Li, 2010). The ineffectiveness in monitoring can be attributed to the fact that a vast majority of independent director nominations are done by the shareholders and managers, and it is common that those appointed are social friends of the controlling shareholders and managers (Qiang, 2003). This implies that independent directors may not be able to effectively monitor the managers or major shareholders who do them a favor by appointing them (Tan and Wang, 2007). Managers and major shareholders control not only the nomination but also the compensation of independent directors (Tan and Wang, 2007). In practice, compensation is designed by the board, subject to approval by shareholders; since independent directors are outnumbered by inside directors, the compensation is in effect determined by managers and controlling shareholders (Xi, 2006). 
Overall, it appears that the roles of independent directors in China can be better explained by the resource dependence perspectives (Pfeffer and Salancik, 1978) in which the roles of independent directors are to counsel and to help with resource acquisition rather than the agency theory (Jensen and Meckling, 1976) in which the role of independent directors is to monitor. Below, we use the resource dependence perspective to develop our hypotheses.

\subsection{Human Capital, Social Capital and Compensation}

According to the resource dependence theory, the role of board of directors is to provide resources such as advice, counsel, and connections to help a firm survive and to improve firm performance (Hillman and Dalziel, 2003). The importance of directors in affecting corporate performance has been well-documented in the literature. For example, a firm led by a chairperson with greater education and professional expertise tends to perform better (Chan et al., 2010; Cheng et al., 2010). Management's education is found to improve Chinese firms' operating and market performance (Kong and Zhang, 2010). While previous research based on Chinese independent directors is limited, Peng (2004) shows that Chinese independent directors help improve firm performance. If human capital can help improve firm performance, the human capital owner (independent director) should be rewarded. Consistently, empirical studies have shown that some human capital factors such as education and experience are positively related to compensation (e.g., Fisher and Govindarajan, 1992).

In this paper, we focus on certain aspects of human capital, i.e., professional qualification, education, and effort. First, since the possession of professional qualification is a signal for professional expertise, we anticipate that those directors with professional qualification should be paid more for their human capital. Second, researchers argue that directors with academic background are appointed on board to portray the prestigious image of and to enhance public 
confidence in the company (Clarke, 2006; Xi, 2006). Also, in the human capital theory, education helps enhance useful skills and knowledge (Becker, 1964), which leads to higher compensation (Fisher and Govindarajan, 1992). Finally, greater effort should be compensated by higher pay; otherwise, the passion and enthusiasm can be burnt out (Cordeiro et al., 2000).

In addition to human capital, previous research shows that social capital contributes to firm success and improves various aspects of firm operation (Chisholm and Nielsen, 2009). Social capital can be defined as 'socially valuable personal attributes and network connections' (Johnson et al., 2011: 1784). Chisholm and Nielsen (2009) argue that social capital is one of the important intangible resources that help a company create economic rents. Both human and social capitals are essential resources for firm operation and value creation (Hillman and Dalziel, 2003). In the Chinese context, researchers find that guanxi (connection or social network) is important for business success (Luo et al., 2012). (Hereafter, we use the words guanxi, connections, and social capital interchangeably.) In a setting with weak market-support institutions like China, research shows that guanxi enhances firm performance (Peng and Luo, 2000), firm valuation (Tang et al., 2013), market expansion, and competitive advantages (Park and Luo, 2001).

Previous research finds that social capital is rewarded in China, i.e., guanxi has positive impacts on the income of urban Chinese workers (Knight and Yueh, 2008). If guanxi is rewarded for other employees, it should be rewarded for independent directors as well. Since guanxi is useful for a firm, a firm is expected to be willing to pay more to attract a well-connected director. We thus anticipate greater pay for an independent director with greater connections.

Hypothesis 1: Ceteris paribus, the compensation for independent directors is positively related to their human capital and social capital.

\subsection{Ownership Structure and Compensation}


According to the contingency framework developed by Filatotchev and Allcock (2010), the organizational context and institutional environment should be considered to better explain compensation practices. One of the distinctive features of the Chinese economy is the dominance of state ownership. We anticipate that state ownership, especially ownership by local government, suppresses independent director compensation. In China, social harmony and equality are culturally and politically cherished (Lin and Lu, 2009). Among other factors such as corruption, income inequality leads to social unrests (Lum, 2006). Surveys show that Chinese workers are sensitive to pay inequality, which is reported as one of the main reasons for leaving a job, and many senior managers indicate that they are reluctant to accept high pay in anticipation that the pay gap may upset colleagues and other employees (Lin and Lu, 2009). Pay disparity is particularly a concern in state-owned enterprises (SOEs thereafter) (SCMP, 2007). Chinese executive compensation appears to be restrained by social equity pressure (Lin and $\mathrm{Lu}, 2009$; Firth et al., 2010); a CEO of an SOE tends to receive less cash compensation (Adithipyangkul et al., 2011).

While SOEs are often lumped together in previous studies, recent research shows that the types of state ownership matters; firm performance (Chen et al., 2009), auditor choice (Wang et al., 2008), and management compensation (Lin and $\mathrm{Lu}, 2009$ ), for example, are determined by whether an SOE is owned by central government (a central SOE thereafter) or by local government (a local SOE thereafter). Following the previous studies, we investigate whether independent director compensation is determined by the types of state ownership. We anticipate that pay inequality concerns affect independent director compensation more significantly in a local SOE than a central SOE due to the nature of the local cadre responsibility system imposed on local government officials, as explained below. 
From 1979, local government officials have been evaluated based on a set of quantitative performance measures such as GDP growth, foreign investment, and birth rate; their career prospects, bonuses, sanctions, and dismissal are linked to the performance evaluation results (Minzner, 2009). Among the performance measures used, social order is important because it is often classified as a 'priority target with veto power', meaning that '[f]ailure to attain these targets unilaterally cancels out all positive work performance in other fields' (Minzner, 2009, p. 68). The local government official's pressure to avoid social unrests is exacerbated by the frequent use of collective rewards and sanctions, in which all the members of the units (not just an individual) are rewarded or sanctioned for meeting or missing the performance targets, respectively (Minzner, 2009). Even though the central government officers may also be subject to similar performance evaluation, previous research shows that the evaluators tend to be more lenient and show favoritism towards an officer/an SOE in a higher political rank in both target setting and performance evaluation in China (Du et al., 2012). Because the local government ranks lower than the central government, a local government unit is expected to be under greater pressure from the performance evaluation system.

Based on the previous research discussed above, the local government units appear to be under greater pressure to control social unrests than the central government units. Because income inequality leads to social unrests (Lum, 2006), to reduce the chance of social upheavals, the local government should not allow its SOEs to set director pay too much greater than other employees. In fact, a previous Chinese study shows that management pay is less suppressed in central SOEs than local SOEs (Lin and Lu, 2009). Because the pressure to lower pay disparity appears to be stronger in a local SOE than a central SOE, we hypothesize that independent director pay is lower in a local SOE than in a central SOE. 
Hypothesis 2: Ceteris paribus, the compensation for independent directors is lower in a local state-owned enterprise than in a central state-owned enterprise.

In addition to the direct impact on the level of compensation, we anticipate that government affiliation affects the relationship between compensation and director human capital and social capital. This is because SOEs tend to receive preferential treatments from the government so that they need to rely less on independent directors for success. Governmentaffiliated firms receive preferential treatments in the input markets ( $\mathrm{Li}, 1996)$. Bank loans and shareholders' funds are also more readily accessible for SOEs (Brandt and Li, 2003), and SOEs have lower probability of financial distress (Wang and Deng, 2006). In case of disputes, the government-affiliated firms are better protected ( $\mathrm{Li}, 1996)$. SOEs also tend to have better credit in the capital market because of the financial insurance provided by the government (government bailout) (Wang et al., 2008). With these competitive advantages, SOEs need to rely less on its independent directors for success while the opposite is true for privately-owned enterprises (POEs). Connections with other business are also found to have stronger positive impact on firm performance for a non-SOE than for an SOE (Peng and Luo, 2000). With greater benefit expected from independent directors, a POE is expected to be willing to pay more for a better director.

Hypothesis 3: Ceteris paribus, the positive relation between compensation and human (social) capital of independent director is stronger in a privately-owned enterprise than in a state-owned enterprise.

\subsection{Legal Institution and Compensation}

Historically, Confucianism has shaped China's culture and values (Han, 2013). The Chinese legal culture is such that law has not been primary; the Confucian principle of $l i$ (custom or norm) took precedence over $f a$ (the codified, formal law imposed by the rulers) (Tucker, 2011). 
The criminal law had been more developed than the civil law (Chen, 2003), and the law was used for incidents between the state and a citizen rather than between citizens themselves (Tucker, 2011). Since the start of the economic reform in 1978, the Chinese formal legal institutions have been enhanced to foster economic development; legislation in important areas such as contracts, business organization, securities and bankruptcy has been enacted (Clarke, 2007). However, with relatively short history, the Chinese formal legal system is still weak (Tucker, 2011), and the judicial independence is still lacking (Chen, 2003). Because Chinese law is vague and imprecise (Tucker, 2011), legal enforcement is subject to government officer's personal interpretations (Park and Luo, 2001). Many judges have no formal education or training in law, and many of them (especially in less developed regions) are former military officers (Chen, 2003). The development of legal institution is found to vary significantly across regions in China (Chen, 2003; Wang et al., 2008).

As discussed earlier, pay disparity can cause social unrest and dissatisfaction among workers or citizens (Lin and Lu, 2009; Lum, 2006). The likelihood of mass dissatisfaction is expected to be influenced by the regional degree of legal development. The development of legal institution has made citizens more aware of their legal rights, and many protests start as legal actions (Lum, 2006). Much of the recent social unrest can be attributed to the development of legal institution (Lum, 2006), and the growing legal consciousness among Chinese people (falï yishi) (Gallagher, 2006). Because of the local cadre responsibility system, the local government is pressured to minimize the chance of social unrest and mass dissatisfaction. The pressure tends to grow stronger as performance evaluation by citizens, such as satisfaction surveys, has gained more importance recently and has been adopted by more local government units (Zhou, 2010). Because local SOEs are under greater pressure to avoid social unrests from pay disparity, and because social unrest is more likely in a region with better legal development (Gallagher, 2006; 
Lum, 2006), we anticipate that local SOES will pay their independent directors less in a region with greater legal development.

Hypothesis 4: Ceteris paribus, the compensation for independent directors in a local state-owned enterprise is lower in a region with better legal development.

\section{Research Method}

\subsection{Sample and Data Collection}

We examine firms from non-finance sectors which are listed on the Shanghai Stock Exchange and the Shenzhen Stock Exchange over the sample period between 2005 and 2009. Our sample consists of 1,508 firms, with 15,523 director-firm-year observations. We collect our data (board information, ownership structure, compensation and director demographic information such as education, professional qualification, gender, age, etc.) from the annual reports.

\subsection{Models}

We use a multivariate regression model (equation (1)) to examine the relations between compensation and director capital (human capital and social capital) and ownership structure as predicted in $\mathrm{H} 1$ and $\mathrm{H} 2$, respectively.

$$
\begin{aligned}
\text { INDDirComp } & =\alpha_{0}+\beta_{1} \text { Director Capital }+\beta_{2} \text { Local SOE }+\beta_{3} \text { Central SOE } \\
& +\beta_{4} \text { Legal Environment Index }+\beta_{5} \text { Control }+\beta_{t} \sum_{t} \text { Year }_{t}+\beta_{j} \sum_{j} \text { Industry }_{j}
\end{aligned}
$$

In H3, we investigate how ownership structure interacts with independent director capital to determine compensation. We expect the positive relation between compensation and director capital to be stronger in a privately-owned enterprise (POE).

INDDirComp $=\alpha_{0}+\beta_{1}$ Director Capital $+\beta_{2}$ Local SOE $+\beta_{3}$ Central SOE 


$$
\begin{aligned}
& +\beta_{4} \text { Director Capital } * P O E+\beta_{5} \text { Legal Environment Index }
\end{aligned}
$$

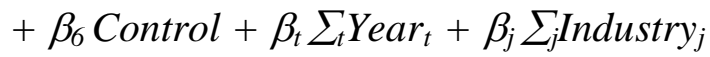

To test H4, we separate our sample into three subsamples: local SOE, central SOE, and POE and run the following regression equation for each subsample. We expect $\beta_{2}$ to be negative for the local SOE subsample.

$$
\begin{gathered}
\text { INDDirComp }=\alpha_{0}+\beta_{1} \text { Director Capital }+\beta_{2} \text { Legal Environment Index } \\
+\beta_{3} \text { Control }+\beta_{t} \sum_{t} \text { Year }_{t}+\beta_{j} \sum_{j} \text { Industry }_{j}
\end{gathered}
$$

\subsection{Measures}

Dependent variables. The variable INDDirComp represents the measures of independent director compensation: Pay and Abnormal Pay. Firstly, Pay is the log of RMB compensation to an independent director. Secondly, Abnormal Pay is the abnormal compensation of an independent director. To estimate Abnormal Pay, we run a regression of Pay on average compensation for inside directors (Average Inside Director Pay), firm size (Firm Size) and cost of living of the province where the firm is located (Living Expense):

$$
\text { Pay }=\alpha_{0}+\beta_{1} \text { Average Inside Director Pay }+\beta_{2} \text { Firm Size }+\beta_{3} \text { Living Expense }
$$

Average Inside Director Pay is the log of average compensation for inside directors. Firm Size is measured by the log of total assets. Living Expense is the log of living consumption index of the region where the firm is located. The coefficients are estimated for the firms in each industry sector for each year over our sample period. Abnormal Pay is the difference between the fitted value of each run of regression for each firm and the actual pay to independent director (Pay). 
Positive and negative values of Abnormal Pay show that the independent director is paid more and less than the 'norm' respectively. ${ }^{1}$

Independent variables. Director Capital is used to refer to the human capital and social capital possessed by independent directors. In this study, we focus on three aspects of human capital, i.e., education, professional expertise, and effort, and we study one aspect of social capital, i.e., connections. Education, which counts the number of schooling years obtained by an independent director (3 years for college education, 4 years for university education, 6 years for a master degree and 9 years for a Ph.D. degree), is our measure of education. Title is a dummy coded 1 if an independent director holds a professional title (e.g., accountant, engineer, etc.) and 0 otherwise. We use Title to measure professional expertise. SubCommittee is the log of the number of subcommittees (e.g., strategy development, audit, nomination, compensation, etc.) attended by an independent director. This is a measure of effort.

Multi-Board, which is the log of the number of directorships held by an independent director, is used to measure connection (guanxi). In many previous studies (e.g., Peng and Luo, 2000; Knight and Yueh, 2008), guanxi is measured based on replies to survey questions such as a question asking the respondent to rank the extensiveness of his/her guanxi. Different respondents can have different perceptions of guanxi extensiveness and their responses are subjective. Rather than measuring the extensiveness of guanxi itself, which is difficult to quantify objectively, we measure guanxi by measuring the outcome of guanxi. Research shows that guanxi helps provide job seekers with access to information about job vacancies (Zang, 2003), and jobs tend to be allocated to those with stronger connections than those with weak connections (Bian and Ang, 1997). Guanxi is especially beneficial for attaining 'soft-skill' jobs, such as manager or director

\footnotetext{
${ }^{1}$ Firth et al. (2010) use average worker's pay and cost of living to estimate abnormal executive director pay. They use the term "excess pay" to refer to the positive values of abnormal pay. In this paper, we follow the methodology of Firth et al. (2010) to estimate the abnormal pay to examine whether the independent directors receive a pay which is higher or lower than the norm for their human and social capital.
} 
jobs, which are non-task-specific and the performance of which is difficult to measure or monitor (Huang, 2008). Those with closer guanxi also tend to stay in the job longer (Hom and Xiao, 2011). Based on these findings, a director with more extensive guanxi is expected to attain and retain a greater number of job positions. We use Multi-Board to capture the broadness of guanxi.

Legal Environment Index is the index of legal development for different provinces in China developed by Fan and Wang (2003). The index is calculated based on (i) the percentage of lawyers of the provincial population, (ii) the percentage of lawsuits pursued by the courts, and (iii) property right protection (Wang et al., 2008). A higher index score represents more developed legal institution. Central SOE is a dummy coded 1 if the firm is an SOE controlled by central government and 0 otherwise. Local SOE is a dummy coded 1 if the firm is an SOE not controlled by central government and 0 otherwise. A central SOE is an SOE whose largest shareholder is a central government authority (such as the Ministry of Finance), while a local SOE is an SOE whose largest shareholder is a local government agency (such as the local offices of the Finance Bureau). $P O E$ is a dummy coded 1 if the firm is a privately-owned enterprise (as opposed to an SOE) and 0 otherwise. We use these variables to investigate the effects of ownership structure.

Control variables. Our control variables consist of director characteristics, board characteristics, and firm characteristics. Firstly, age and gender are found to be related to work performance (Cheng et al, 2010), and performance is shown to be related to non-executive director compensation (Cordeiro et al., 2000). Because age and gender are expected to be related to compensation, we control for director's age and gender. Age is the age of independent director. Gender is a dummy coded 1 if the independent director is a female and 0 otherwise.

In addition to director characteristics, we include board and firm characteristics as prior studies show that compensation is influenced by corporate governance, capital structure, and performance (Firth et al., 2010). Board Size is the log of the number of directors on board, and 
Outside Director Ratio is the proportion of independent directors on board. Leverage is debt to assets ratio. ROA (return on total assets) is employed as a measure of firm performance. Firm Size (log of total assets) is our measure of firm size. In addition, an older firm which is wellestablished may have more resources to pay its directors. We thus add Firm Age, the log of the number of years a firm is established, as a control variable. The variable, Living Expense, is also included to control for the living expense level of the region where the firm is located. Finally, Year, which represents the year dummies, and Industry, which represents the industry dummies, are added to control for the fixed effects through the years during the sample period across different industries.

\section{Results and Discussion}

Table 1 reports the descriptive statistics. Our sample consists of 1,508 firms with 15,523 director-firm-year observations. In our sample, independent director annual pay ranges from RMB 1,000 to RMB 450,000, with a mean of RMB 46,132.94. Around $12 \%$ of the directors are females and the mean age is 51.73 years. Approximately, $71 \%$ of independent directors have professional qualifications. On average, an independent director has 4.46 years of tertiary education. In terms of effort and connections, an independent director sits in 1.61 subcommittees in the focal firm and holds 0.68 external appointments as a director (inside or independent) in other companies.

Insert Table 1 about here

Out of the total 15,523 director-firm-year observations, $45.5 \%$ belong to local SOEs while $18.2 \%$ belong to central SOEs. The average legal environment index is 5.92 , with the maximum 
of 7.97 in Beijing and the minimum of 2.62 in Hunan. Firm size (total assets) ranges from RMB 39.63 million to RMB 866,475 million, with a mean of RMB 7,079.2 million. The mean age of the sample firms is around 11 years. The return on total asset and debt to total asset ratio on average are about $4.37 \%$ and $49 \%$, respectively. The board of directors consists of about 9.97 members. The mean proportion of independent directors on board is around $36 \%$, with a median of $33 \%$, which is consistent with the CSRC's Guideline that requires at least one third of the directors to be independent.

The correlation matrix is shown in Table 2. None of the explanatory variables are extremely correlated so that it is unlikely that multicollinearity is a concern for the multivariate analysis.

Insert Table 2 about here

Table 3 presents the results of our test of $\mathrm{H} 1$ and $\mathrm{H} 2$, i.e., whether independent director compensation increases with human capital and social capital, and whether independent directors are paid less in a local SOE. Consistent with H1, an independent director with greater human capital and connections is paid more. The coefficients on Multi-Board, Education, and SubCommittee are positive and statistically significant for both Pay and Abnormal Pay. While we do not find independent director compensation to be significantly related to professional expertise in the full sample, we find a positive and significant relationship in the local SOE subsample (to be discussed below). Our results are consistent with the previous studies such as Fisher and Govindarajan (1992) which find CEO compensation is positively related to CEO human capital. Our results also add to the literature on social capital and compensation. The previous evidence is mixed. Meyerson (1994) finds management income is positively related to social capital in 
Sweden, while Johnson et al. (2011) conclude that there is no support for the hypothesized positive relationship between pay and director's social capital in the U.S. It appears that national institution affects the relationship between pay and social capital. Future research may investigate this interesting issue further.

Following the contingency framework developed by Filatotchev and Allcock (2010), we consider the organizational context and institutional environment in China to better explain compensation practices. We investigate the impacts of ownership structure and regional legal development. In H2, we argue that due to the local cadre responsibility system (Minzner, 2009), a local SOE has strong motivation to suppress director pay to avoid social unrests. Consistent with H2, we also find the coefficients on Local SOE for Pay and Abnormal Pay are negative and statistically significant. For Central SOE, however, we find the positive relation is statistically significant for Abnormal Pay; indicating that a central SOE tends to pay its independent directors more than a local SOE and a POE. Our results are consistent with a study by Lin and Lu (2009), which finds that management pay is higher in central SOEs than local SOEs.

Insert Table 3 about here

In addition to the direct impact on the level of compensation, we anticipate that ownership structure affects the relationship between compensation and director capital. Because POEs do not receive preferential treatments from the government, we anticipate that they need to rely more on independent directors for survival and success and hence will be willing to pay more for director capital (H3). Table 4 reports the results for $\mathrm{H} 3$ whether the relations between compensation and director's human capital and connections are stronger in a POE. While we do not find a POE pays more for connections (as measured by the number of external director 
positions (Multi-Board)), we show that a POE pays more for effort and professional expertise. The interaction term Title*POE has positive and statistically significant coefficients of both for Pay and Abnormal Pay. The coefficients on SubCommittee $* P O E$ are also positive and statistically significant both for both pay measures. Our results are in the same vein as the previous US research investigating the moderating effects of firm characteristics on the relation between CEO pay and CEO human capital (Geletkanycz et al., 2001). Contrary to our expectation, a POE pays less for education. Education*POE has negative and statistically significant coefficients for both pay measures.

Insert Table 4 about here

The results from Table 4 suggest that a certain attribute of director capital may be more desirable in a certain type of firms. To explore this further and to test $\mathrm{H} 4$, we separate our sample into three subsamples: local SOE, central SOE, and POE. The regression analysis results are shown in Table 5. Panel A reports the results for the dependent variable Pay, while Panel B reports the results for the dependent variable Abnormal Pay.

We hypothesize that the legal institution development is negatively related to independent director compensation in local SOEs. Supporting H4, we find that Legal Environment Index is negatively and significantly related to Pay and Abnormal Pay in the local SOE subsample. We also find Legal Environment Index is positively related to Pay and Abnormal Pay in POEs but is not significantly related to Pay and Abnormal Pay in central SOEs. Our results add to the previous research which documents the impacts of legal institution on various economic outcomes such as firm valuation, ownership structure and capital market development (La Porta et al., 2008). 
In addition, we find that social capital (guanxi) appears to be desirable in all types of firms, the coefficients for Multi-Board are positive and statistically significant in all subsamples in Panel A. While Education is positively associated with Pay for local and central SOEs, Education is not significantly related to Pay for POEs. In addition, while Title is not significantly related to Pay in SOEs, Title is positively related to Pay in POEs. We also find that local SOEs and POEs pay their independent directors more for effort, as measured by SubCommittee, but effort is not significantly related to Pay in central SOEs. Panel B shows consistent results for the dependent variable Abnormal Pay. Overall, our results suggest that a certain attribute of director capital may be more desirable in a certain type of firms, and pay appears to be determined differently, depending on the ownership structure.

\section{Conclusion}

Given different legal and national institutions, it is questionable whether the theories and empirical findings based on the western market economies are valid in other settings. Previous research shows that some western theories and empirical findings are applicable to China (see e.g., Firth et al., 2010). This paper adds to the literature by exploring what determines independent director compensation in China. We find that independent director compensation in China is determined by director human capital (education, professional expertise, and effort), social capital (connections), ownership structure, and legal institutional environment, providing evidence from a transitional economy to support the resource dependence perspective and Filatotchev and Allcock's (2010) contingency framework. One of the limitations of our study is that our study (and many of the previous studies) investigates the determinants of independent director compensation across firms and industries. Future research may consider a longitudinal 
study to investigate the changes over time. These inter-temporal studies will be particularly relevant to China as China continues to develop to be more market-oriented. 


\section{References}

Adithipyangkul, P., Alon, I., \& Zhang, T.Y. (2011). Executive perks: Compensation and corporate performance in China. Asia Pacific Journal of Management, 28(2), 401-425.

Amit, R., Ding, Y., Villalonga, B., \& Zhang, H. (2009). The Role of Institutional Development in the Prevalence and Value of Family Firms. Working paper, University of Pennsylvania, Pennsylvania.

Becker, G.S. (1964). Human Capital. New York: Columbia University Press.

Bian, Y., \& Ang, S. (1997). Guanxi networks and job mobility in China and Singapore. Social Forces, 75(3), 981-1005.

Brandt, L., \& Li, H. (2003). Bank discrimination in transition economies: ideology, information or incentives? Journal of Comparative Economics, 31, 387-413.

Chan, R.Y.K., Cheng, L.T.W., \& Leung, T.Y. (2010). Corporate performance implications of relational demographic differences: On age and titles of chairpersons vs. general managers of listed Chinese companies. British Journal of Management, 22(1), 96-113.

Chen, Z. (2003). Capital markets and legal development: The China case. China Economic Review, 14, 451-472.

Chen, G., Firth, M., \& Xu, L. (2009). Does the type of ownership control matter? Evidence from China's listed companies. Journal of Banking and Finance, 33, 171-181.

Cheng, L.T.W., Chan, R.Y.K., \& Leung, T.Y. (2010). Management demography and corporate performance: Evidence from China. International Business Review, 19(3), 261-275.

Chisholm, A. M., \& Nielsen, K, (2009). Social capital and the resource-based view of the firm. International Studies of Management and Organization, 39(2), 7-32.

Clarke, D.C. (2006). The independent director in Chinese corporate governance. Delaware Journal of Corporate Law, 31, 125-228.

Clarke, D.C. (2007). Legislation for a market economy in China. The China Quarterly, 191, 567585.

Cordeiro, J., Veliyath, R., \& Eramus, E. (2000). An empirical investigation of the determinants of outside director compensation. Corporate Governance: An International Review, 8 (3), 268-279.

Das, D.K. (2012). The Chinese economy: A rationalized account of its transition and growth. Chinese Economy, 45(4), 7-38.

Du, F., Tang, G., \& Young, S.M. (2012). Influence activities and favoritism in subjective performance evaluation: Evidence from Chinese state-owned enterprises. Accounting Review, 87(5), 1555-1588.

Fan, G., \& Wang, X. (2003). The Report on the Relative Process of Marketization of Each Region in China. The Economic Science Press (in Chinese).

Filatotchev, I., \& Allcock, D. (2010). Corporate governance and executive remuneration: A contingency framework. Academy of Management Perspectives, 24(1), 20-33.

Firth, M., Leung, T.Y., \& Rui, O.M. (2010). Justifying top management pay in a transitional economy. Journal of Empirical Finance, 17, 852-866.

Fisher, J., \& Govindarajan, V. (1992). Profit center manager compensation: An examination of market, political and human capital factors. Strategic Management Journal, 13, 205-217.

Gallagher, Mary E. (2006). Mobilizing the law in China: "Informed disenchantment" and the development of legal consciousness. Law \& Society Review, 40, 783-816.

Geletkanycz, M.A., Boyd, B.K., \& Finkelstein, S. (2001). The strategic value of CEO external directorate networks: implications for CEO compensation. Strategic Management Journal, 22, 889-898. 
Hahn, P.D., \& Lasfer, M. (2011). The compensation of non-executive directors: Rationale, form, and findings. Journal of Management and Governance, 15, 589-601.

Han, P. (2013). Confucian leadership and the rising Chinese economy. Chinese Economy, 46(2), 107-127.

Hillman, A.J., \& Dalziel, T. (2003). Boards of directors and firm performance: Integrating agency and resource dependence perspectives. Academy of Management Review, 28, 383-396.

Hom, P.W. \& Xiao, Z. (2011). Embedding social networks: How guanxi ties reinforce Chinese employees' retention. Organizational Behaviour and Human Decision Processes, 116, 188-202.

Huang, X. (2008). Guanxi networks and job searches in China's emerging labour market: A quantitative investigation. Work Employment and Society, 22(3), 467-484.

Jensen, M., \& Meckling, W. (1976). Theory of the firm: Managerial behavior, agency costs and ownership structure. Journal of Financial Economics, 3(4), 305-360.

Johnson, S., Schnatterly, K., Bolton, J. F., \& Tuggle, C. (2011). Antecedents of new director social capital. Journal of Management Studies, 48(8), 1782-1803.

Knight, J. \& Yueh, L. (2008). The role of social capital in the labour market in China. Economics of Transition, 16(3), 389-414.

Kong, V.X., \& Zhang, J. (2010). The effects of managerial education and firm-ownership structure. Chinese Economy, 43(6), 34-53.

La Porta, R., Lopez-de-Silanes, F., and Shleifer, A. (2008). The economic consequences of legal origins. Journal of Economic Literature, 46(2), 285-332.

$\mathrm{Li}, \mathrm{D}$. (1996). A theory of ambiguous property right in transition economies: The case of the Chinese non-state sector. Journal of Comparative Economics, 23, 1-19.

Li, Z. (2010). China's corporate governance: The Mingxing Electric Power Company Scandal. Chinese Economy, 43(3): 77-102.

Lin, B.X. \& Lu, R. (2009). Managerial power and compensation gap and firm performance Evidence from Chinese public listed companies. Global Finance Journal, 20, 153-164.

Liu, H., \& Fong, M.W.L. (2010). Board characteristics of medium and large Chinese companies. Corporate Governance, 10(2), 163-175.

Lum, T. (2006). Social unrest in China (RL33416). Washington, DC: Congressional Research Service. Downloaded on 17/12/14 from http://digitalcommons.ilr.cornell.edu/crs/19/ .

Luo, Y., Huang, Y., \& Wang, S.L. (2012). Guanxi and organizational performance: A metaanalysis. Management and Organization Review, 8 (1), 139-172.

Meyerson, E. M. (1994). Human Capital, Social Capital and Compensation: The relative contribution of social contacts to managers' incomes. Acta Sociologica, 37, 383-399.

Minzner, Carl F. (2009). Riots and cover-ups: Counterproductive control of local agents in China. University of Pennsylvania Journal of International Law, 31(1), 53-123.

Park, S.H. \& Luo, Y. (2001). Guanxi and organizational dynamics: Organizational networking in Chinese firms. Strategic Management Journal, 22, 455-477.

Peng, M.W. (2004). Outside directors and firm performance during institutional transitions. Strategic Management Journal, 25,453-471.

Peng, M.W. \& Luo, Y. (2000). Managerial ties and firm performance in a transition economy: The nature of a micro-macro link. Academy of Management Journal, 43(3), 486-501.

Pfeffer, J., \& Salancik, G.R. (1978). The External Control of Organization: A Resource Dependence Perspective. New York: Harper.

Qiang, Q. (2003). Corporate governance and state-owned shares in China listed companies. Journal of Asian Economics, 14(5), 771-783.

SCMP (2007). Beijing probes hefty pay rises at state firms. South China Morning Post, May 16. 
Soong, J. (2014). Is China becoming the core of regional trade and market integration in the AsiaPacific? Chinese Economy, 47(3), 3-7.

Tan, L.H., \& Wang, J. (2007). Modelling an effective corporate governance system for China's listed state-owned enterprises: Issues and challenges in a transitional economy. Journal of Corporate Law Studies, 7,143-183.

Tang, Y., Ye, S. \& Zhou, J. (2013). Political connections, legal environment, and corporate valuation in Chinese public family firms. Chinese Economy, 46(6): 32-49.

Tucker, M. (2011). "Guanxi!"-"Gesundheit!" an alternative view on the "rule of law" panacea in China. Vermont Law Review, 35, 689-715.

Wang, Q., Wong, T.J., \& Xia, L. (2008). State ownership, the institutional environment, and auditor choice: Evidence from China. Journal of Accounting and Economics, 46, 112-134.

Wang, Z. \& Deng, X. (2006). Corporate governance and financial distress: Evidence from Chinese listed companies. Chinese Economy, 39(5), 5-27.

$\mathrm{Xi}, \mathrm{C}$. (2006). In search of an effective monitoring board model: Board reforms and the political economy of corporate law in China. Connecticut Journal of International Law, 22(1), 1-46.

Zang, X. (2003). Network resources and job search in urban China. Journal of Sociology, 39(2), 115-129.

Zhou, Z. (2010). Performance management reforms in mainland China. In E.M. Berman, M.J. Moon, and H. Choi (Eds.), Public Administration in East Asia: Mainland China, Japan, South Korea, Taiwan, 117-143. Taylor \& Francis, Parkway, NW. 


\section{Table 1}

\section{Descriptive Statistics}

\begin{tabular}{|c|c|c|c|c|c|c|c|}
\hline & $\begin{array}{c}\text { Dummy } \\
\text { Code }=1\end{array}$ & $\begin{array}{c}\text { Dummy } \\
\text { Code }=0\end{array}$ & Mean & Median & Maximum & Minimum & $\frac{\text { Standard }}{\text { Deviation }}$ \\
\hline Pay $(\ln )$ & & & $\overline{10.59}$ & $\overline{10.60}$ & 13.02 & 6.91 & 0.56 \\
\hline $\operatorname{Pay}(R M B)$ & & & $46,132.94$ & $40,000.00$ & $450,000.00$ & $1,000.00$ & $28,131.30$ \\
\hline Abnormal Pay & & & -0.09 & -0.05 & 1.93 & -3.38 & 0.48 \\
\hline Multi-Board (ln) & & & 0.37 & 0.00 & 1.95 & 0.00 & 0.51 \\
\hline Multi-Board (position) & & & 0.68 & 0.00 & 6.00 & 0.00 & 1.08 \\
\hline Education (ln) & & & 1.38 & 1.61 & 2.30 & 0.00 & 0.91 \\
\hline Education (year) & & & 4.46 & 4.00 & 9.00 & 0.00 & 3.36 \\
\hline Title & 11081 & 4442 & & & & & \\
\hline SubCommittee (ln) & & & 0.80 & 1.10 & 1.79 & 0.00 & 0.60 \\
\hline Subcommittee (position) & & & 1.61 & 2.00 & 5.00 & 0.00 & 1.34 \\
\hline Female & 1902 & 13621 & & & & & \\
\hline Age $(\ln )$ & & & 3.93 & 3.91 & 4.50 & 3.33 & 0.20 \\
\hline Age (year) & & & 51.73 & 50.00 & 90.00 & 28.00 & 10.23 \\
\hline Outside Director Ratio & & & 0.36 & 0.33 & 0.67 & 0.13 & 0.05 \\
\hline Board Size (ln) & & & 2.28 & 2.20 & 2.94 & 1.61 & 0.22 \\
\hline Board Size (members) & & & 9.97 & 9.00 & 19.00 & 5.00 & 2.24 \\
\hline$P O E$ & 5631 & 9892 & & & & & \\
\hline Central SOE & 2829 & 12694 & & & & & \\
\hline Local SOE & 7063 & 8460 & & & & & \\
\hline Legal Environment Index & & & 5.92 & 6.24 & 7.97 & 2.62 & 1.27 \\
\hline Firm Size (ln) & & & 21.65 & 21.54 & 27.45 & 17.50 & 1.19 \\
\hline Firm Size ( million RMB) & & & $7,079.22$ & $2,262.35$ & $866,475.00$ & 39.63 & $29,843.42$ \\
\hline Leverage & & & 0.49 & 0.50 & 0.90 & 0.01 & 0.18 \\
\hline$R O A$ & & & 0.04 & 0.04 & 1.76 & -2.75 & 0.08 \\
\hline Firm Age (ln) & & & 2.41 & 2.48 & 3.33 & 0.00 & 0.43 \\
\hline Firm Age (year) & & & 11.06 & 11.00 & 27.00 & 1.00 & 4.36 \\
\hline Living Expense (ln) & & & 9.35 & 9.31 & 9.95 & 8.69 & 0.30 \\
\hline Living Expense (RMB) & & & $11,978.43$ & $11,055.13$ & $20,992.35$ & $5,928.79$ & $3,597.90$ \\
\hline
\end{tabular}

The number of observations is 15,523. Pay is the log of compensation (in RMB) to independent director. Abnormal Pay is the abnormal compensation of independent director. Multi-Board is the log of the number of multiple board directorships held by an independent director. Education is the log of the tertiary schooling years of an independent director, with 3 years for college education, 4 years for university education, 6 years for master degree education, and 9 years for Ph.D. degree. Title is dummy coded 1 if an independent director holds a professional qualification (e.g., accountant, engineer, and economist). SubCommittee is the log of the number of subcommittees attended by an independent director. Legal Environment Index shows the degree of legal environment development of the region a firm is located. Female is a dummy coded 1 if an independent director is a female and 0 otherwise. Age is the log of the age of an independent director. $P O E$ is a dummy coded 1 if a firm is a privately-owned firm and 0 otherwise. Outside Director Ratio is the ratio of the number of independent directors to total number of directors. Board Size is the log of the number of directors on board. Central SOE is a dummy coded 1 if a firm is a central SOE. Local SOE is a dummy coded 1 if a firm is a local SOE. Firm Size is the log of total assets. Leverage is the debt to total asset ratio. ROA is the return on total assets. Firm Age is the log of firm age. Living Expense is the log of the living consumption index of the region a firm is located. 
Table 2

\section{Correlation Matrix}

\begin{tabular}{|c|c|c|c|c|c|c|c|c|c|c|c|c|c|c|c|c|c|}
\hline & 1 & 2 & 3 & 4 & 5 & 6 & 7 & 8 & 9 & 10 & 11 & 12 & 13 & 14 & 15 & 16 & 17 \\
\hline 1 Pay & 1.00 & & & & & & & & & & & & & & & & \\
\hline 2 Abnormal Pay & $0.79 * *$ & 1.00 & & & & & & & & & & & & & & & \\
\hline 3 Multi-Board & $0.10^{* *}$ & $0.05^{* *}$ & 1.00 & & & & & & & & & & & & & & \\
\hline 4 SubCommittee & $0.05^{* *}$ & $0.04 * *$ & $0.03^{* *}$ & 1.00 & & & & & & & & & & & & & \\
\hline 5 Education & $0.05^{* *}$ & $0.04 * *$ & $0.34 * *$ & $-0.05^{* *}$ & 1.00 & & & & & & & & & & & & \\
\hline 6 Title & $0.02 * *$ & $0.04 * *$ & $0.29 * *$ & $-0.03^{* *}$ & $0.40^{* *}$ & 1.00 & & & & & & & & & & & \\
\hline 7 Female & $-0.05 * *$ & $-0.02 * *$ & $-0.07 * *$ & -0.01 & $-0.03 * *$ & $-0.02 * *$ & 1.00 & & & & & & & & & & \\
\hline 8 Age & $0.10^{* *}$ & $0.04 * *$ & 0.01 & $-0.03 * *$ & $-0.15^{* *}$ & $0.05^{* *}$ & $-0.10^{* *}$ & 1.00 & & & & & & & & & \\
\hline 9 Outside Director Ratio & $0.02 * *$ & $-0.02 * *$ & -0.01 & 0.01 & $-0.02 * *$ & $-0.05 * *$ & $-0.02 *$ & $0.03 * *$ & 1.00 & & & & & & & & \\
\hline 10 Board Size & $0.04 * *$ & $-0.04 * *$ & -0.01 & $-0.07 * *$ & $0.03 * *$ & $0.02 *$ & $-0.02 * *$ & $0.04 * *$ & $-0.14 * *$ & 1.00 & & & & & & & \\
\hline 11 Central SOE & $0.12 * *$ & $0.03^{* *}$ & 0.02 & 0.01 & $0.02 *$ & -0.01 & $-0.04 * *$ & $0.03 * *$ & $-0.02 * *$ & $0.14 * *$ & 1.00 & & & & & & \\
\hline 12 Local SOE & $-0.06 * *$ & $-0.06 * *$ & $0.03 * *$ & $0.03 * *$ & $-0.03 * *$ & $0.03 * *$ & 0.00 & $0.04 * *$ & $-0.03 * *$ & $0.11 * *$ & $-0.43 * *$ & 1.00 & & & & & \\
\hline 13 Legal Environment Index & $0.19 * *$ & $-0.13 * *$ & $0.02 * *$ & $-0.04 * *$ & $0.04 * *$ & -0.02 & $-0.02^{* *}$ & $0.05^{* *}$ & $0.02 * *$ & $-0.03 * *$ & $0.09 * *$ & $-0.13^{* *}$ & 1.00 & & & & \\
\hline 14 Firm Size & $0.35^{* *}$ & $-0.08 * *$ & $0.06^{* *}$ & 0.00 & $0.02 *$ & $0.02 *$ & $-0.04 * *$ & $0.11 * *$ & $0.02 *$ & $0.27 * *$ & $0.22 * *$ & $0.15^{* *}$ & $0.09 * *$ & 1.00 & & & \\
\hline 15 Leverage & $0.06^{* *}$ & $-0.03 * *$ & 0.00 & $0.04^{* *}$ & $-0.02 *$ & 0.00 & $-0.02 *$ & 0.00 & 0.00 & $0.13^{* *}$ & $0.09 * *$ & $0.08^{* *}$ & $-0.09 * *$ & $0.37 * *$ & 1.00 & & \\
\hline $16 R O A$ & $0.10^{* *}$ & $0.05^{* *}$ & $0.04 * *$ & $-0.06^{* *}$ & $0.05^{* *}$ & $0.02 * *$ & 0.00 & 0.01 & $-0.02 * *$ & $-0.02 * *$ & $-0.03^{* *}$ & $-0.07 * *$ & $0.03^{* *}$ & $0.03^{* *}$ & $-0.28 * *$ & 1.00 & \\
\hline 17 Firm Age & $0.02 * *$ & -0.01 & $0.03 * *$ & $0.21 * *$ & $-0.07 * *$ & $-0.03 * *$ & $0.02 *$ & -0.01 & -0.01 & 0.01 & -0.01 & $0.18^{* *}$ & $-0.07 * *$ & $0.13 * *$ & $0.19 * *$ & $-0.13 * *$ & 1.00 \\
\hline 18 Living Expense & $0.25^{* *}$ & $-0.14 * *$ & $0.06 * *$ & $0.10^{* *}$ & 0.00 & $-0.04 * *$ & $-0.02 * *$ & $0.06^{* *}$ & $0.07 * *$ & $-0.04 * *$ & $0.07 * *$ & $-0.16^{* *}$ & $0.72 * *$ & $0.06^{* *}$ & $-0.08 * *$ & 0.01 & $0.03 * *$ \\
\hline
\end{tabular}

Number of observations is 15,523. Pay is the log of compensation (in RMB) to independent director. Abnormal Pay is the abnormal compensation of independent director. Multi-Board is the log of the number of multiple board directorships held by an independent director. Education is the log of the tertiary schooling years of an independent director, with 3 years for college education, 4 years for university education, 6 years for master degree education, and 9 years for Ph.D. degree. Title is dummy coded 1 if an independent director holds a professional qualification (e.g., accountant, engineer, and economist). SubCommittee is the log of the number of subcommittees attended by an independent director. Female is a dummy coded 1 if an independent director is a female and 0 otherwise. Age is the log of the age of an independent director. Outside Director Ratio is the ratio of the number of independent directors to total number of directors. Board Size is the log of the number of directors on board. Central SOE is a dummy coded 1 if a firm is a central SOE. Local SOE is a dummy coded 1 if a firm is a local SOE. Legal Environment Index shows the degree of legal environment development of the region a firm is located. Firm Size is the log of total assets. Leverage is the debt to total asset ratio. ROA is the return on total assets. Firm Age is the log of firm age. Living Expense is the log of the living consumption index of the region a firm is located.

$* p \leq 0.05$

$* * p \leq 0.01$ 
Table 3

Regression Analysis (H1 and H2)

\begin{tabular}{lcc|cc}
\hline & \multicolumn{2}{c|}{ Pay } & \multicolumn{2}{c}{ Abnormal Pay } \\
& Coefficient & p-value & Coefficient & p-value \\
\cline { 2 - 5 } Intercept & 3.18 & 0.00 & 2.54 & 0.00 \\
Multi-Board & 0.05 & $0.00^{* *}$ & 0.04 & $0.00^{* *}$ \\
Education & 0.02 & $0.00^{* *}$ & 0.02 & $0.00^{* *}$ \\
Title & 0.00 & 0.79 & 0.01 & 0.46 \\
SubCommittee & 0.04 & $0.00^{* *}$ & 0.04 & $0.00^{* *}$ \\
Legal Environment Index & -0.01 & $0.02^{*}$ & -0.02 & $0.00^{* *}$ \\
Central SOE & 0.01 & 0.26 & 0.05 & $0.00^{* *}$ \\
Local SOE & -0.07 & $0.00^{* *}$ & -0.06 & $0.00^{* *}$ \\
Female & -0.03 & $0.01^{* *}$ & -0.03 & $0.02^{*}$ \\
Age & 0.15 & $0.00^{* *}$ & 0.15 & $0.00^{* *}$ \\
Outside Director Ratio & -0.13 & 0.12 & -0.22 & $0.00^{* *}$ \\
Board Size & -0.10 & $0.00^{* *}$ & -0.05 & $0.01^{* *}$ \\
Firm Size & 0.17 & $0.00^{* *}$ & -0.02 & $0.00^{* *}$ \\
Leverage & -0.06 & $0.02^{*}$ & -0.05 & 0.06 \\
ROA & 0.51 & $0.00^{* *}$ & 0.31 & $0.00^{* *}$ \\
Firm Age & -0.03 & $0.01 * *$ & 0.00 & 0.91 \\
Living Expense & 0.37 & $0.00^{* *}$ & -0.26 & $0.00^{* *}$ \\
Industry Dummies Included & & & & \\
Year Dummies Included & & & & \\
Adjusted R-square & 0.21 & & 0.05 & \\
F Statistic & 11.87 & & 24.78 & \\
p-value & 0.00 & & 0.00 & \\
N & 15523 & & 15523 & \\
\hline
\end{tabular}

Pay is the log of compensation (in RMB) to independent director. Abnormal Pay is the abnormal compensation of independent director. Multi-Board is the log of the number of multiple board directorships held by an independent director. Education is the log of the tertiary schooling years of an independent director, with 3 years for college education, 4 years for university education, 6 years for master degree education, and 9 years for Ph.D. degree. Title is dummy coded 1 if an independent director holds a professional qualification (e.g., accountant, engineer, and economist). SubCommittee is the log of the number of subcommittees attended by an independent director. Legal Environment Index shows the degree of legal environment development of the region a firm is located. Central SOE is a dummy coded 1 if a firm is a central SOE. Local SOE is a dummy coded 1 if a firm is a local SOE. Female is a dummy coded 1 if an independent director is a female and 0 otherwise. Age is the log of the age of an independent director. Outside Director Ratio is the ratio of the number of independent directors to total number of directors. Board Size is the log of the number of directors on board. Firm Size is the log of total assets. Leverage is the debt to total asset ratio. ROA is the return on total assets. Firm Age is the log of firm age. Living Expense is the log of the living consumption index of the region a firm is located.

$$
\begin{gathered}
* p \leq 0.05 \\
* * p \leq 0.01
\end{gathered}
$$


Table 4

\section{Regression Analysis (H3)}

\begin{tabular}{lcc|cc}
\hline & \multicolumn{2}{c|}{ Pay } & \multicolumn{2}{c}{ Abnormal Pay } \\
& Coefficient & p-value & Coefficient & p-value \\
\cline { 2 - 5 } Intercept & 3.60 & 0.00 & 2.76 & 0.00 \\
Multi-Board & 0.06 & $0.00^{* *}$ & 0.05 & $0.00^{* *}$ \\
Education & 0.03 & $0.00^{* *}$ & 0.03 & $0.00^{* *}$ \\
Title & -0.02 & 0.07 & -0.02 & 0.18 \\
SubCommittee & 0.02 & $0.01^{*}$ & 0.03 & $0.00^{* *}$ \\
Multi-Board*POE & -0.02 & 0.37 & -0.01 & 0.45 \\
Education*POE & -0.02 & $0.04^{*}$ & -0.03 & $0.00^{* *}$ \\
Title*POE & 0.06 & $0.00^{* *}$ & 0.06 & $0.00^{* *}$ \\
SubCommittee*POE & 0.03 & $0.05^{*}$ & 0.03 & $0.05^{*}$ \\
Legal Environment Index & -0.00 & 0.93 & -0.01 & $0.04^{*}$ \\
Central SOE & 0.05 & $0.03^{*}$ & 0.07 & $0.00^{* *}$ \\
Local SOE & -0.04 & 0.12 & -0.03 & 0.13 \\
Female & -0.03 & $0.01^{* *}$ & -0.03 & $0.02^{*}$ \\
Age & 0.16 & $0.00^{* *}$ & 0.14 & $0.00^{* *}$ \\
Outside Director Ratio & -0.09 & 0.25 & -0.18 & $0.02^{*}$ \\
Board Size & -0.08 & $0.00^{* *}$ & -0.04 & $0.05^{*}$ \\
Firm Size & 0.16 & $0.00^{* *}$ & -0.03 & $0.00^{* *}$ \\
Leverage & -0.07 & $0.00^{* *}$ & -0.04 & 0.12 \\
ROA & 0.53 & $0.00^{* *}$ & 0.31 & $0.00^{* *}$ \\
Firm Age & -0.03 & $0.01^{* *}$ & -0.00 & 0.85 \\
Living Expense & 0.34 & $0.00^{* *}$ & -0.28 & $0.00^{* *}$ \\
Industry Dummies Included & & & & \\
Year Dummies Included & & & & \\
Adjusted R-square & 0.20 & & 0.05 & \\
F Statistic & 111.94 & & 24.18 & \\
p-value & 0.00 & & 0.00 & \\
N & 15523 & & 15523 & \\
\hline
\end{tabular}

Pay is the log of compensation (in RMB) to independent director. Abnormal Pay is the abnormal compensation of independent director. Multi-Board is the $\log$ of the number of multiple board directorships held by an independent director. Education is the log of the tertiary schooling years of an independent director, with 3 years for college education, 4 years for university education, 6 years for master degree education, and 9 years for Ph.D. degree. Title is dummy coded 1 if an independent director holds a professional qualification (e.g., accountant, engineer, and economist). SubCommittee is the $\log$ of the number of subcommittees attended by an independent director. Legal Environment Index shows the degree of legal environment development of the region a firm is located. Central SOE is a dummy coded 1 if a firm is a central SOE. Local SOE is a dummy coded 1 if a firm is a local SOE. Female is a dummy coded 1 if an independent director is a female and 0 otherwise. Age is the log of the age of an independent director. $P O E$ is a dummy coded 1 if a firm is a privately-owned firm and 0 otherwise. Outside Director Ratio is the ratio of the number of independent directors to total number of directors. Board Size is the log of the number of directors on board. Firm Size is the log of total assets. Leverage is the debt to total asset ratio. ROA is the return on total assets. Firm Age is the log of firm age. Living Expense is the log of the living consumption index of the region a firm is located.

$$
\begin{aligned}
* p & \leq 0.05 \\
* * & \leq 0.01
\end{aligned}
$$




\section{Table 5}

\section{Regression Analysis (H4)}

Panel A: Dependent Variable = Pay

\begin{tabular}{|c|c|c|c|c|c|c|c|c|}
\hline & \multicolumn{2}{|c|}{$\begin{array}{c}\text { Full Sample } \\
\text { Pay }\end{array}$} & \multicolumn{2}{|c|}{$\begin{array}{c}\text { Local SOEs } \\
\text { Pay }\end{array}$} & \multicolumn{2}{|c|}{$\begin{array}{c}\text { Central SOEs } \\
\text { Pay }\end{array}$} & \multicolumn{2}{|c|}{$\begin{array}{l}\text { POEs } \\
\text { Pay }\end{array}$} \\
\hline & Coefficient & p-value & Coefficient & p-value & Coefficient & $\mathrm{p}$-value & Coefficient & p-value \\
\hline Intercept & 3.18 & 0.00 & 3.21 & 0.00 & 3.59 & 0.00 & 5.24 & 0.00 \\
\hline Multi-Board & 0.05 & $0.00 * *$ & 0.06 & $0.00 * *$ & 0.04 & $0.04 *$ & 0.05 & $0.00 * *$ \\
\hline Education & 0.02 & $0.00 * *$ & 0.03 & $0.00 * *$ & 0.03 & $0.01 * *$ & 0.00 & 0.79 \\
\hline Title & 0.00 & 0.79 & -0.03 & 0.06 & 0.01 & 0.72 & 0.03 & $0.04 *$ \\
\hline SubCommittee & 0.04 & $0.00 * *$ & 0.03 & $0.00 * *$ & 0.01 & 0.48 & 0.05 & $0.00 * *$ \\
\hline Legal Environment Index & -0.01 & $0.02 *$ & -0.02 & $0.01 * *$ & 0.01 & 0.61 & 0.03 & $0.02 *$ \\
\hline Central SOE & 0.01 & 0.26 & & & & & & \\
\hline Local SOE & -0.07 & $0.00 * *$ & & & & & & \\
\hline Female & -0.03 & $0.01 * *$ & -0.02 & 0.20 & -0.02 & 0.57 & -0.06 & $0.00 * *$ \\
\hline Age & 0.15 & $0.00 * *$ & 0.15 & $0.00 * *$ & 0.17 & $0.00 * *$ & 0.12 & $0.00 * *$ \\
\hline Outside Director Ratio & -0.13 & 0.12 & -0.21 & 0.08 & 0.58 & $0.00 * *$ & -0.32 & $0.03 *$ \\
\hline Board Size & -0.10 & $0.00 * *$ & -0.03 & 0.27 & -0.33 & $0.00 * *$ & -0.03 & 0.39 \\
\hline Firm Size & 0.17 & $0.00 * *$ & 0.16 & $0.00 * *$ & 0.18 & $0.00 * *$ & 0.14 & $0.00 * *$ \\
\hline Leverage & -0.06 & $0.02 *$ & -0.01 & 0.81 & -0.21 & $0.00 * *$ & -0.04 & 0.37 \\
\hline$R O A$ & 0.51 & $0.00 * *$ & 0.75 & $0.00 * *$ & 0.58 & $0.00 * *$ & 0.16 & $0.02 *$ \\
\hline Firm Age & -0.03 & $0.01 * *$ & 0.10 & $0.00 * *$ & -0.08 & $0.00 * *$ & -0.04 & $0.00 * *$ \\
\hline Living Expense & 0.37 & $0.00 * *$ & 0.34 & $0.00 * *$ & 0.33 & $0.00 * *$ & 0.21 & $0.00 * *$ \\
\hline Industry Dummies & & & & & & & & \\
\hline Included & & & & & & & & \\
\hline Year Dummies Included & & & & & & & & \\
\hline Adjusted R-square & 0.21 & & 0.21 & & 0.34 & & 0.15 & \\
\hline F Statistic & 111.87 & & 65.09 & & 47.31 & & 30.87 & \\
\hline p-value & 0.00 & & 0.00 & & 0.00 & & 0.00 & \\
\hline $\mathrm{N}$ & 15523 & & 7063 & & 2829 & & 5631 & \\
\hline
\end{tabular}


Panel B: Dependent Variable = Abnormal Pay

\begin{tabular}{|c|c|c|c|c|c|c|c|c|}
\hline & \multicolumn{2}{|c|}{$\begin{array}{c}\text { Full Sample } \\
\text { Abnormal Pay }\end{array}$} & \multicolumn{2}{|c|}{$\begin{array}{l}\text { Local SOEs } \\
\text { Abnormal Pay }\end{array}$} & \multicolumn{2}{|c|}{$\begin{array}{c}\text { Central SOEs } \\
\text { Abnormal Pay }\end{array}$} & \multicolumn{2}{|c|}{$\begin{array}{c}\text { POEs } \\
\text { Abnormal Pay }\end{array}$} \\
\hline & Coefficient & p-value & Coefficient & p-value & Coefficient & p-value & Coefficient & $\mathrm{p}$-value \\
\hline Intercept & 2.54 & 0.00 & 2.28 & 0.00 & 2.86 & 0.00 & 5.21 & 0.00 \\
\hline Multi-Board & 0.04 & $0.00 * *$ & 0.05 & $0.00 * *$ & 0.03 & $0.04 *$ & 0.05 & $0.00 * *$ \\
\hline Education & 0.02 & $0.00 * *$ & 0.04 & $0.00 * *$ & 0.03 & $0.03 *$ & 0.00 & 0.87 \\
\hline Title & 0.01 & 0.46 & -0.02 & 0.08 & 0.01 & 0.51 & 0.04 & $0.01 * *$ \\
\hline SubCommittee & 0.04 & $0.00 * *$ & 0.04 & $0.00 * *$ & 0.00 & 0.97 & 0.04 & $0.00 * *$ \\
\hline Legal Environment Index & -0.02 & $0.00 * *$ & -0.02 & $0.00 * *$ & 0.01 & 0.37 & 0.02 & $0.03 *$ \\
\hline Central SOE & 0.05 & $0.00 * *$ & & & & & & \\
\hline Local SOE & -0.06 & $0.00 * *$ & & & & & & \\
\hline Female & -0.03 & $0.02 *$ & -0.02 & 0.18 & -0.01 & 0.61 & -0.05 & $0.01 * *$ \\
\hline Age & 0.15 & $0.00 * *$ & 0.14 & $0.00 * *$ & 0.17 & $0.00 * *$ & 0.12 & $0.00 * *$ \\
\hline Outside Director Ratio & -0.22 & $0.00 * *$ & -0.24 & $0.04 *$ & 0.53 & $0.00 * *$ & -0.57 & $0.00 * *$ \\
\hline Board Size & -0.05 & $0.01 * *$ & 0.01 & 0.63 & -0.16 & $0.00 * *$ & -0.04 & 0.24 \\
\hline Firm Size & -0.02 & $0.00 * *$ & -0.03 & $0.00 * *$ & -0.01 & 0.08 & -0.05 & $0.00 * *$ \\
\hline Leverage & -0.05 & 0.06 & -0.05 & 0.21 & -0.12 & $0.04 *$ & 0.05 & 0.27 \\
\hline$R O A$ & 0.31 & $0.00 * *$ & 0.48 & $0.00 * *$ & 0.27 & 0.17 & 0.07 & 0.33 \\
\hline Firm Age & 0.00 & 0.91 & 0.10 & $0.00 * *$ & -0.01 & 0.71 & -0.04 & $0.00 * *$ \\
\hline Living Expense & -0.26 & $0.00 * *$ & -0.26 & $0.00 * *$ & -0.33 & $0.00 * *$ & -0.49 & $0.00 * *$ \\
\hline Industry Dummies & & & & & & & & \\
\hline Included & & & & & & & & \\
\hline Year Dummies Included & & & & & & & & \\
\hline Adjusted R-square & 0.05 & & 0.06 & & 0.06 & & 0.07 & \\
\hline F Statistic & 24.78 & & 16.81 & & 6.86 & & 14.66 & \\
\hline p-value & 0.00 & & 0.00 & & 0.00 & & 0.00 & \\
\hline $\mathrm{N}$ & 15523 & & 7063 & & 2829 & & 5631 & \\
\hline
\end{tabular}

Pay is the log of compensation (in RMB) to independent director. Abnormal Pay is the abnormal compensation of independent director. Multi-Board is the log of the number of multiple board directorships held by an independent director. Education is the log of the tertiary schooling years of an independent director, with 3 years for college education, 4 years for university education, 6 years for master degree education, and 9 years for Ph.D. degree. Title is dummy coded 1 if an independent director holds a professional qualification (e.g., accountant, engineer, and economist). SubCommittee is the $\log$ of the number of subcommittees attended by an independent director. Legal Environment Index shows the degree of legal environment development of the region a firm is located. Central SOE is a dummy coded 1 if a firm is a central SOE. LOcal SOE is a dummy coded 1 if a firm is a local SOE. Female is a dummy coded 1 if an independent director is a female and 0 otherwise. Age is the log of the age of an independent director. Outside Director Ratio is the ratio of the number of independent directors to total number of directors. Board Size is the log of the number of directors on board. Firm Size is the log of total assets. Leverage is the debt to total asset ratio. ROA is the return on total assets. Firm Age is the log of firm age. Living Expense is the log of the living consumption index of the region a firm is located.

$* p \leq 0.05$

$* * p \leq 0.01$ 